\title{
How Can China Learn from the Experience of the US to Improve the Export Control System of Aerospace Products
}

\author{
Yuxi Liu \\ School of Public Affairs, University of Science and Technology of China, \\ Wu Hu Lu Street, Hefei 230000, China
}

\begin{abstract}
Aerospace products are different from ordinary commodities and usually have the characteristic of military use or dual-use application. This paper examines the US export policy system for aerospace products, including research on relevant US laws, policy institutions, policy instruments, and process mechanisms. By comparing the institutional differences between China and the United States, this paper analyzes the characteristics of the US export control system and the shortcomings of China's export control system, and then provides reference for the development of China's aerospace industry and the reform of China's export control policies.
\end{abstract}

Keywords: export control; aerospace; international trade; policy research

DOI: $10.7176 / \mathrm{IAGS} / 72-03$

Publication date:May $31^{\text {st }} 2019$

\section{Introduction}

In the trade of intellectual property-intensive products between China and the United States, aerospace products cover military goods, dual-use goods and civilian goods. Therefore, aviation aerospace technology has a special status and certain representativeness in export control. For the United States, aerospace technology is closely related to the US national security, technological superiority and diplomatic interests. It is one of the few hightech fields in the United States that adopts the most stringent regulations. At the same time, China's aerospace industry has also ushered in a period of vigorous development. Strengthening the research on export control policies of related industries is necessary to promote the development of China's aerospace technology. At present, China does not have specific legislation for aerospace products, and the relevant legal systems and management mechanisms are not perfect. As a big aviation manufacturing country and aerospace powerhouse, China's export control system for aerospace technology is not as rigorous and comprehensive as the United States. China should learn from the US's experience in export control of aerospace technology according to its own development needs to improve the export control policy of China's aerospace technology when exchanging and cooperating with other countries on aerospace technology.

\section{Components of the US Aerospace Products Export Control System}

\subsection{The export control legal system}

The legal system of US export controls is relatively complex. The specific parts that constitute the export control legal system include the laws passed by Congress, the executive orders signed by the president, the regulations and lists issued by the export control departments such as the State Council and the Ministry of Commerce, and the multilateral control treaties signed by the government. Currently, major export control laws include the Export Administration Act (EAA), the Arms Export Control Act (AECA), the International Traffic in Arms Regulations (ITAR), the Export Administration Regulations (EAR), and the International Emergency Economic Powers Act (IEEPA). These laws all involve export controls on aerospace technology.

The Arms Export Control Act (AECA) and the International Traffic in Arms Regulations (ITAR) are the main legal basis for the US Department of State export control of military aerospace products. All military technologies, including military aerospace technology, are subject to these two laws. The US export control of defense-type aerospace technology focuses on the perspective of security interests. According to AECA, all individuals and entities involved in the export of defense aerospace technology to foreign countries are required to register in the United States. If a US company illegally exports and leaks defense-type aerospace technology, or if a foreign company illegally steals US related technology, criminal penalties should be imposed on those who violate the law according to AECA. "ITAR" was established by the US State Department under the AECA. The US State Department submits quarterly and annual reports in Congress based on the requirements of the AECA. The ability to export a military technology product to a foreign country requires the State Council to issue an export license in accordance with the specific provisions of the ITAR and report the authorization to Congress. At the same time, the proposed export license should also be reported. In addition, each year's National Defense Authorization Act (NDAA) and the Foreign Relations Authorization Act (FRAA) often impose clear restrictions on aerospace arms sales.

The Export Administration Act (EAA) and the Export Administration Regulations (EAR) are the main legal basis for the export control of dual-use aerospace technology by the US Department of Commerce. In 2001, after 
the expiration of EAA, the United States used IEEPA as the interim legal basis for EAR. The Bureau of Industry and Security is responsible for the annual revision of the Export Administration Regulations. In 2018, the US Congress passed the Export Control Reform Act, which provides a new permanent legal basis for EAR The change in the Export Control Reform Act is to increase export controls on PNT technology and hypersonic aerodynamics.

\subsection{The government departments responsible for export control}

Aerospace products for military use are subject to export control by the Directorate of Defense Trade Controls of State Department (DDTC). DDTC is responsible for the export control of aerospace technology originating in the United States for military purposes in accordance with AECA and ITAR. These items will be recorded in the "United States Munitions Lists" in the appendix of the ITAR. Taking aerospace products as an example, the production, transfer and use of all space equipment, including launching tools, navigation equipment, ground stations and space optoelectronic arrays, are illegal without the permission of the government. The Directorate of Defense Trade Controls of State Department (DDTC) and the Department of Homeland Security's Immigration and Customs Enforcement (ICE) work closely on the export enforcement of aerospace items. The Bureau of International Security and Nonproliferation of the State Council (ISN) is responsible for nuclear-related aerospace technology and nonproliferation of missile systems. ISN may impose sanctions on foreign space companies on the grounds of nuclear proliferation. For example, in April 2018, the department imposed sanctions on 28 entities in some countries under the Iran, North Korea, Syria Nonproliferation Act (INKSNA).

The US Department of Commerce is the main functional department responsible for export control of dualuse aerospace items. For example, the Bureau of Industry and Security (BIS) of the Department of Commerce is responsible for the export of key components of commercial jet engines and commercial satellites under the Export Administration Regulations. The Under Secretary of Commerce for International Trade specializes in export control enforcement and divides this work into three offices for specific operations: Office of Antiboycott Compliance (OAC), Office of Enforcement Analysis (OEA), and Office of Export Enforcement (OEE).

The Department of Homeland Security's law enforcement is based on the US Customs and Border Protection Authorization Act and the US Immigration and Customs Act. U.S. Customs and Border Protection (CBP) is responsible for inspecting the aerospace products to be exported and seizing or confiscating suspicious or illegal goods found during the inspection. In turn, CBP informed U.S. Immigration and Customs Enforcement (ICE) of the case, which conducted an in-depth investigation of the export. ICE is the investigative agency for illegal exports. Its Homeland Security Investigations (HIS) used its more than 10,000 staff, including 6,700 agents in 47 countries around the world, to investigate the export of sensitive products. According to the survey results, HIS can impose penalties on individuals or companies that illegally sell aerospace technology, such as fines, economic sanctions, and revoked export licenses, in accordance with relevant US export control laws and regulations.

The Department of the Treasury considers whether export aerospace products will have an impact on the US domestic economy. In addition, the Department of the Treasury is also responsible for the implementation of the trade embargo policy, which can impose economic sanctions on individuals and companies. The Office of Foreign Assets Control (OFAC) of the Department of the Treasury is responsible for the specific implementation of economic and trade sanctions, thereby achieving export control of aerospace technology. Sanctions include loan restrictions, asset controls, asset freezes, export bans, and trade restrictions.

In 2012, the Obama administration established the Export Enforcement Coordination Center (E2C2) and an Information Triage Unit (ITU) to improve the management of US export controls. At the same time, the White House has designated the Office of the National Counterintelligence Executive to coordinate export control issues involving intelligence agencies. E2C2 is composed of officials from the Department of Homeland Security, the Department of Commerce, the Department of Justice, the Department of Energy, the Treasury, and the Department of Defense. It is affiliated with the Department of Homeland Security. ITU is managed by the Department of Commerce.

\subsection{The main policy instruments for export control.}

The export licensing system is the main policy instrument for US export controls. Except for Canada, any merchandise exported by the United States to any country requires an export license. The Bureau of Industry and Security divides export licenses into General Licenses, Validated Licenses and Special Complex Licenses. The General License is applied directly to the Department of Commerce without special approval. The General License is further divided into GTDA (Technical data available to all destination) and GTDR (Technical data under restriction). The former allows general technology and products to be exported abroad, while the latter allows only exports to Group A and Group B countries in the Country Classification List. The Export Administration Regulations stipulate that an export license should be applied for, but it may be waived for some reason. This situation is called a license exception. The US licensing exceptions are grouped into different 
countries (regions), which are divided into groups A to E, and the degree of control is becoming stricter.

The United States not only grouped countries for licensing exceptions, but also grouped exporting countries (regions) according to the degree of export control. This grouping is called the Commerce Country Chart. Different countries in different groups are subject to different export control policies. At present, the United States divides countries (regions) into five groups in the world, and the export controls are from loose to strict, followed by Group A, Group B, Group C, Group D, and Group E.

The US government regulates the export of goods through a control list system. The control list mainly includes the Commodity/Commerce Control List (CCL), the United States Munitions List (USML), and the Nuclear Regulatory Commission Controls (NRCC). The Commerce Control List is primarily the responsibility of the US Department of Commerce, and the United States Munitions List is the responsibility of the US Department of State. The Department of Commerce updates the CCL annually after seeking the opinions of other departments and agencies such as the Department of Defense; the US State Department updates the USML after consulting with the Department of Defense. CCL classifies all products included in it, including ten categories, each of which is subdivided into five subcategories A, B, C, D, and E. Aerospace products subject to commercial control lists are mainly concentrated in Category 6, Category 7, and Category 9. The US weapons control list includes 21 major categories such as aviation and aerospace, and is further divided into several subcategories under 21 major categories. Compared to CCL, USML is updated at a low frequency. In 2013, USML made major adjustments to aerospace products: some less sensitive aerospace products and components were included in the CCL.

The United States has not only set up a list of items and country classifications, but also has an Entity List, also known as a "blacklist," for the purpose of reviewing end-use and end-users. When a company is listed on the entity list, it is difficult for the exporter to obtain export licenses from the US government when exporting to the company. The End-User Review Committee (ERC) is the primary responsible agency for the list of entities. The list of entities to be listed only needs to be recognized by multiple members of ERC, and the removed list needs to seek the disapproval of all members of ERC. In addition to the Entity List, BIS also has an unconfirmed list of entities that the Department of Commerce is still unable to determine its actual situation after end-use and end-user verification.

In addition to the above-mentioned permanent control mechanisms, the United States also implements specific export control policies for some countries from time to time. For example, the National Defense Authorization Act of 2013 officially reclassified aerospace products such as satellites into the CCL, but Section 1261 still stipulates that it is not allowed to export, re-export or transfer satellites to China, not allowed in China or by China launches US-made satellites and does not allow Chinese-made launch vehicles to launch US satellites.

Table 1. Commerce Country Chart

\begin{tabular}{|l|l|l|}
\hline Group & Degree of export control & Representative country \\
\hline A & Loose, good political and trading partners. & Canada, Australia, UK, France, Germany, Japan \\
\hline B & Slightly loose, friendly country. & Mexico, Brazil, Egypt, Thailand, Turkey \\
\hline C & Control. & Unpublished/reserved. \\
\hline D & Strict control. & China, Albania, Afghanistan, Pakistan, Iran \\
\hline E & Embargoed country. & Cuba, Iraq, Libya, North Korea, Rwanda \\
\hline
\end{tabular}

Table 2. Classification of items in CCL

\begin{tabular}{|l|l|}
\hline NO. & Commerce Control List Categories \\
\hline 0 & Nuclear \& Miscellaneous \\
\hline 1 & $\begin{array}{l}\text { Materials, Chemicals, Microorganisms } \\
\text { and Toxins }\end{array}$ \\
\hline 2 & Materials Processing \\
\hline 3 & Electronics \\
\hline 4 & Computers \\
\hline $5-1$ & Telecommunications \\
\hline $5-2$ & Information Security \\
\hline 6 & Sensors and Lasers \\
\hline 7 & Navigation and Avionics \\
\hline 8 & Marine \\
\hline 9 & Aerospace and Propulsion \\
\hline
\end{tabular}

\begin{tabular}{|l|l|}
\hline Subcategories & Product Groups \\
\hline A & $\begin{array}{l}\text { Systems, Equipment and } \\
\text { Components }\end{array}$ \\
\hline B & $\begin{array}{l}\text { Test, Inspection and } \\
\text { Production Equipment }\end{array}$ \\
\hline C & Material \\
\hline D & Software \\
\hline E & Technology \\
\hline
\end{tabular}

\section{Characteristics of the US aerospace technology export control system}


3.1 The US export control system is complex and rigorous.

The US export control legal system is both large and detailed. It includes laws promulgated by Congress, multilateral and bilateral export control treaties signed by the US government, administrative orders issued by the US president, and export control regulations issued by export control agencies. In addition to these laws and treaties, the President of the United States has also issued different administrative orders for export control based on specific circumstances.

The export control agencies in the United States are diverse. Due to the complexity of the US export control legal system and the decentralization of power, a large number of institutions are involved in the implementation and management of export controls. The Department of Commerce, the US Department of State, and the Department of Energy are the three major export control agencies. In addition, the Department of the Treasury, the Department of Defense, the Department of Justice, the Department of Homeland Security, and even the National Security Council are involved in the decision-making and management of export controls.

US export control procedures are also extremely complex. Due to the large number of export control agencies and the unique export control procedures of each export control agency, the US export control procedures are extremely complicated. The Department of Commerce's dual-use items export control procedures are different from the State Department and the Department of Defense's arms export control procedures. The Export Administration Regulations (EAR) license procedures are different from the International Traffic in Arms Regulations (ITAR). Regardless of it is a dual-use export license or an arms export license, cross-institutional review is an essential part, which further increases the complexity of the export control process.

\subsection{The US export controls have extraterritoriality.}

The extraterritorial jurisdiction of US export control policies is the most systematic and comprehensive in all countries of the world. US export control jurisdictions include citizens and permanent residents of the United States, companies registered or operated in the United States, overseas molecular agencies of US companies, companies operating abroad but controlled by the United States, companies and products that produce goods overseas under the US License Agreement, items imported from the United States, patents and other technologies from the United States. Therefore, the export control of the United States is very broad in scope, and it can be said to be all-encompassing.

The characteristics of the extraterritorial jurisdiction of US export controls are reflected in three aspects. First, countries that re-export goods and technologies imported from the United States need to obtain prior US consent. Second, when goods exported from technology or parts produced in the United States are exported, they are subject to US regulation. Third, it prohibits the export of anyone within US jurisdiction, including US companies, citizens, and US-controlled branches overseas, regardless of where the product comes from.

\subsection{The US export control mechanism is a combination of unilateral and multilateral.}

Unlike the unilateral export control policies imposed by the vast majority of countries in the world, US export controls rely on the rigor of unilateral export controls and the coordination of multilateral export controls. In order to prevent US goods from leaving the United States and entering those regulated countries, the United States' unilateral export control policy must rely on multilateral cooperation mechanisms, such as the Paris Coordinating Committee during the period 1950-1994, the Missile Technology Control Regime (MTCR) established in 1987, the Australian Group (AG) established in 1985, the Nuclear Suppliers Group (NSG), the Wassenaar Arrangement (WA) and the United Nations embargo measures, etc.

Since the US export control mechanism is a combination of unilateral and multilateral controls, the regulatory provisions issued by the international multilateral regulatory agencies contracted by the United States can also become the legal basis for US recognition. For example, the United States has repeatedly issued export controls on Chinese products and Chinese companies on the grounds that China has spread missile technology to other countries.

\section{How can China learn from the experience of the United States to improve the export control system for aerospace products?}

4.1 Improving the Export Control Legal System of China's Aerospace Products

At present, the laws and regulations related to the export control of aerospace technology in China's legal system include the Foreign Trade Law, the Regulations on the Administration of Import and Export of Technology, the Measures for the Administration of Export Classification of Civil Aviation Parts, and the Dual-Use Items and Measures for the Administration of General Licenses for Technology Exports, Regulations on Export Control of Missiles and Related Items and Technologies, etc. Most of these regulations are departmental regulations. Compared with the Export Administration Law and the Arms Export Control Law passed by the US Congress, the Chinese legal effect level is low, the legal system is scattered, and the laws of import and export are mixed. In the past decade, China's aerospace technology has developed rapidly, but if it's managed in the form of 
departmental regulations. It is difficult to update the control list every year like the United States. Therefore, these regulations are highly lagging and ambiguous, and have poor guidance and operability in practice. In addition, China will also distinguish technology from product legislation. In fact, with the development of intellectual property and technological advancement, technology and products have become difficult to separate. Separate legislation increases the difficulty of management and may lead to conflicts of law.

In response to this problem, China needs to change the model of import and export merger legislation and form two systems of the import law and the export law. At the same time, China should clarify the two management systems of military product export control and dual-use product export control, and abolish the management mode of separation of technology and products. China should speed up the legislation of the Export Administration Law and establish a special "Double-us Control List" and "Military Control List" in accordance with this law. The dynamically adjusted list should be managed and updated by the Ministry of Commerce and the Ministry of National Defense. The law should clarify the right of review and investigation of government agencies, such as the Ministry of Commerce, in the areas of trade secrets and technical secrets. In addition, with the strength of China's comprehensive national strength, the US's country classification system, blacklist system and other export control methods can also be used by China.

\subsection{Innovative Management Mechanism and Improve Management Authority}

According to the Regulations of the People's Republic of China on Technology Import and Export Management, China's Ministry of Commerce is responsible for the export management of aerospace technology. In practice, when the Ministry of Commerce reviews export technologies and products, it is difficult to understand the important information such as professional and technical grades. Therefore, the review process of export control must be carried out by defense units, military departments and research institutes to enhance the accuracy of export control and reduce losses to enterprises or countries.

China can follow the example of establishing a joint censorship system in the United States, set up an "Export Review Committee", and formulate its charter and management measures. Led by the Ministry of Commerce, the Central Military Commission, the Ministry of National Defense, the Ministry of Foreign Affairs, the Ministry of Industry and Information Technology, the Customs and relevant national defense scientific research units jointly participated in the review. The committee should also be responsible for technical intelligence, including the background of import and export companies, the technical level of products, the ultimate purpose of technology exports and end users, the technical capabilities of imports, the substitutability and criticality of technology. In addition, the department can also be responsible for the formulation and implementation of anti-export control and anti-economic sanctions related policies. Building a service-oriented government is a requirement of the Communist Party of China and the Chinese government. The information disclosure system for export control does not contradict the confidentiality system. The government departments responsible for export control should inform exporters of their rights and obligations, procedures and duration of export review, and export risks and responsibilities, remedies and compensation methods, etc.

\subsection{China Should Appropriately Expand Extraterritorial Jurisdiction and Establish a Technology Re-export Control System}

The US export control system has clear extraterritoriality. Although there are many problems, China can learn from its reasonable parts. In the past, China ignored the importance and management of re-exports. Although China has set up a re-export control policy in some areas of aerospace technology such as missile technology, there are no relevant rules and it cannot be implemented. Moderate re-export control is conducive to safeguarding China's national security, intellectual property rights and economic interests.

In response to this problem, China should clarify the technical and legal implications of terms such as "export to third parties". Before the legislation of the Export Control Law, it should at least be elaborated in the Regulations on the Administration of Technology Import and Export of the People's Republic of China. Export control agencies should clarify their responsibilities for re-export management, and exporters, importers and end users should also guarantee re-export issues in trade contracts.

\subsection{China Should Actively Improve Economic and Trade Relations with Other Countries and Strive to Join the International Multilateral Export Control Mechanism}

Major aerospace manufacturing countries such as the United States, France, and Israel are involved in several multilateral export control mechanisms, such as the Australian Group, the Missile Control Mechanism, and the Wassenaar Arrangement. These multilateral control mechanisms not only provide a platform for cooperation among countries in the world, but also promote mutual understanding, mutual trust and understanding. To a certain extent, these multilateral mechanisms have also promoted the export of dual-use items and even military supplies among members.

China should actively participate in the international multilateral export control mechanism, change passive 
to active, and strengthen the exchanges with countries around the world in the attitude of a responsible big country. China can also strengthen trade coordination with individual countries and regions such as the European Union, ASEAN, Japan, and Russia, gradually reduce trade barriers and export controls, and strengthen cooperation on some dual-use aerospace technologies. In addition, China can also explore the establishment of its own multilateral export control mechanism, such as the establishment of a non-proliferation mechanism based on the Shanghai Cooperation Organization. In short, the effectiveness of export control depends not only on unilateral regulation, but also on national cooperation.

\section{Conclusion}

The United States has a relatively complete export control legal system. AECA and ITAR are the basis for US export control of military aerospace products. EAA, EAR and ECRA are the basis for US export controls on civil and dual-use aerospace technology. The US export control policy system not only has legal support, but also a series of policy tools, including export licensing systems, country classification systems, control list systems, entity list systems, and specialized discrimination initiatives. The State Department is responsible for reviewing military items (including satellites) based on its United States Munitions Lists. The Department of Commerce is responsible for the review of civilian and dual-use items based on its Commerce Country Chart, Commerce Control List and Entity List. In addition, the Department of Defense, the Department of Homeland Security, and the Treasury are involved in many departments. The US export control system is more complete than China. Therefore, China should improve its export control mechanism based on US experience. In particular, it is necessary to implement separate legislation on import and export, merger legislation on technology and items, double-line management of military products and dual-use items, joint review of export controls, appropriate expansion of extraterritorial jurisdiction, and active participation of multilateral controls.

\section{References}

Michael C. Mineiro. (2018).Space Technology Export Controls and International Cooperation in Outer Space. Springer.

Richard Weitz. (2015) U.S. Export Control System Reform: Promoting the Interests of the U.S. Army. U.S. Army War College.

Robert O. Keohane, Joseph S. Nye.(2011). Power \& Interdependence (4th Edition). Pearson.

JaeBin Ahn,Mary Amiti,David E. Weinstein.Trade Finance and the Great Trade Collapse. (2011). American Economic Review,3,298-302. 